\title{
Hooked Tail
}

National Cancer Institute

\section{Source}

National Cancer Institute. Hooked Tail. NCI Thesaurus. Code C124544.

A finding that the tail has an approximate 180 degree bend or curve. 